\title{
Penurunan Jumlah Bakteri Staphylococcus aureus pada Susu Kambing Peranakan Etawa setelah Teat Dipping dalam Dekok Daun Pepaya (Carica papaya L.)
}

\section{Decreased Amount of Staphylococcus aureus in Etawa Crossbreed Goat Milk after Teat Dipping in Papaya Leaf Dekok (Carica papaya L.)}

\author{
A. S. Abni*, R. Febriyanti, D. A. Mucra, J. Handoko, \& E. Saleh \\ Program Studi Peternakan, Fakultas Pertanian dan Peternakan \\ Universitas Islam Negeri Sultan Syarif Kasim Riau \\ HR. Soebrantas Panam Km. 15 No. 155, Tuah Madani, Kec. Tampan, Kota Pekanbaru, Riau 28293 \\ *Email korespondensi: aisahsabila3108@gmail.com
}

\author{
- Diterima: 04 Januari 2021 • Direvisi: 07 Februari 2021 • Disetujui: 15 Februari 2021
}

\begin{abstract}
ABSTRAK. Penggunaan dekok daun pepaya (Carica papaya L.) sebagai antiseptik alami untuk teat dipping adalah salah satu cara yang dapat dilakukan untuk mencegah mastitis pada ternak kambing Peranakan Etawa (PE). Dekok daun pepaya mengandung alkaloid, triterpenoid, steroid, flavonoid, saponin dan tannin yang bersifat sebagai anti bakteri dan anti radang alami, sehingga mampu menekan pertumbuhan bakteri S. aureus yang merupakan bakteri utama penyebab mastitis pada ternak kambing PE. Penelitian ini menggunakan Rancangan Acak Lengkap (RAL) dengan 4 perlakuan dan 4 ulangan. Ulangan dalam penelitian berupa 16 ekor kambing PE laktasi yang diambil susunya sebagai sampel. Perlakuan dalam penelitian terdiri dari P0= Povidone Iodine 10\%, P1= Dekok Daun Pepaya 30\%, P2= Dekok Daun Pepaya 50\% dan P3= Dekok Daun Pepaya 70\%. Parameter penelitian meliputi nilai pH, Total Plate Count (TPC) dan jumlah bakteri S. auerus pada sampel susu kambing PE yang diamati. Hasil penelitian menunjukkan penggunaan dekok daun pepaya berpengaruh sangat nyata $(\mathrm{P}<0,01)$ dalam mempertahankan nilai $\mathrm{pH}(6,49-6,57)$, menurunkan nilai TPC $\left(1,794 \times 10^{6}-0,034 \times 10^{6}\right)$ dan nilai jumlah koloni bakteri S. aureus $\left(0,70 \times 10^{2}-0,67 \times 10^{2}\right)$ pada sampel susu kambing PE yang diteliti. Kesimpulan penelitian adalah penggunaan dekok daun pepaya 70\% (P3) sebagai larutan teat dipping merupakan perlakuan dengan konsentrasi terbaik yang memiliki efektivitas yang sama dengan povidone iodine $10 \%$.
\end{abstract}

Kata kunci: Dekok daun pepaya, kambing PE, mastitis, s. aureus, teat dipping

ABSTRACT. The using of papaya leaf dekok (Carica papaya L.) as a natural disinfectant for teat dipping is the one of methods that can be done to prevent mastitis in Etawa crossbreed goat. Papaya leaf dekok contains alkaloids, triterpenoids, steroids, flavonoids, saponins and tannins that act as natural antibacterial and anti-inflammatory, so as to suppress the growth of Staphylococcus aureus which is the major bacteria that trigger udder inflammation (mastitis) for Etawa crossbreed goat. This study used a completely randomized design (CRD) with four processes and four replicas. The replication in this study were 16 lactating Etawa crossbreed goat and their milk was taken as a sample. The treatment of this study consisted of $P 0=10 \%$ povidone iodine, $P 1=30 \%$ papaya leaf dekok, $P 2=50 \%$ papaya leaf dekok and $P 3=70 \%$ papaya leaf dekok. The parameter of study are $p H$ value, total plate count (TPC) and the number of S. aureus in the Etawa crossbreed goat milk sample. The study showed that the use of papaya leaf dekok was not very significantly different $(P>0,01)$ to maintain the values of $\mathrm{pH}(6,49-6,57)$, decrease the levels of TPC $\left(1,794 \times 10^{6}-0,034 \times 10^{6}\right)$ and S. auerus colony $\left(2,70 \times 10^{2}-0,67 x\right.$ $\left.10^{2}\right)$ in the Etawa crossbreed goat milk sample. The conclusion of this study is that the use of papaya leaf dekok $70 \%$ (P3) as a teat dipping liquid is the best concentration treatment that has the same effect as 10\% povidone iodine.

Keywords: Etawa crossbreed goat, mastitis, papaya leaf dekok, s. aureus, teat dipping

\section{PENDAHULUAN}

Kambing Peranakan Etawa (PE) merupakan jenis kambing yang banyak dimanfaatkan untuk diambil susunya. Susu kambing memiliki kelebihan berupa butir lemak yang lebih kecil dibandingkan susu sapi serta memiliki proporsi asam lemak rantai pendek dalam jumlah yang relatif tinggi sehingga mudah dicerna. Susu kambing juga mengandung mineral, kalsium serta fosfor yang baik untuk pertumbuhan bayi (Albenzio dan Santilo, 2011). Meningkatnya pengetahuan masyarakat akan tingginya nilai gizi pada susu kambing ini, juga meningkatkan permintaan susu kambing dipasaran. 
Meningkatnya jumlah permintaan susu kambing oleh konsumen juga meningkatkan peluang usaha bagi para peternak. Beternak kambing PE mulai digeluti dan dikembangkan dimasyarakat. Kendala yang paling sering dialami oleh peternak kambing PE adalah terjadinya radang ambing atau mastitis pada ternak. Mastitis menyebabkan terjadinya penurunan produksi susu sekitar 10-25\%. Mastitis juga menyebabkan kematian anak karena tidak mendapatkan kolostrum meningkatnya jumlah hewan yang harus dikeluarkan karena sakit, peningkatan biaya pengobatan yang cukup mahal dan tingginya Jumlah Sel Somatik (JSS) pada susu sehingga ditolak oleh pasar. Mikroorganisme Staphylococcus sp. dan Streptococcus sp. merupakan dua bakteri utama penyebab mastitis klinis dan subklinis pada ternak perah di Indonesia. Penelitian Suwito dkk. (2013) menyatakan bakteri $S$. aureus sebagai penyebab terjadinya kasus mastitis klinis $55,55 \%$ pada ternak kambing.

Pencegahan mastitis dapat dilakukan dengan teat dipping menggunakan bahan antiseptik seperti iodine, chlorhexidin dan chlorine setelah pemerahan (Siregar, 2010). Namun, penggunaan larutan antiseptik sintetik tersebut dapat mengakibatkan adanya residu bahan kimia pada susu yang dihasilkan. Penggunaan dekok daun pepaya (Carica papaya L.) dapat dijadikan sebagai alternatif pengganti larutan antiseptik sintetik untuk teat dipping. Daun pepaya positif mengandung alkaloid, triterpenoid, steroid, flavonoid, saponin dan tannin (A'yun dan Laily, 2015).

Kandungan alkaloid, flavonoid, saponin dan tanin dalam daun pepaya berkhasiat sebagai antiseptik, anti bakteri, anti jamur dan anti radang alami sehingga baik digunakan sebagai larutan antiseptik untuk teat dipping dan diharapkan mampu mengurangi bakteri penyebab mastitis pada ternak kambing PE. Selain itu, daun pepaya tidak sulit didapatkan dan mudah diolah menjadi larutan antiseptik untuk teat dipping.

Berdasarkan uraian diatas maka telah dilakukan penelitian mengenai: "Penggunaan Dekok Daun Pepaya (Carica papaya L.) pada Perlakuan Teat Dipping terhadap Penurunan Jumlah Bakteri Staphylococcus aureus dalam
Susu Kambing Peranakan Etawa". Hal ini bertujuan untuk mengetahui pengaruh penggunaan dekok daun pepaya (Carica papaya L.) sebagai antiseptik alternatif dan persentase terbaiknya pada perlakuan teat dipping terhadap penurunan jumlah bakteri $S$. aureus dalam susu kambing PE.

\section{METODE PENELITIAN}

Penelitian telah melalui uji kelayakan etik penelitian oleh Komisi Etik Penelitian Fakultas Pertanian dan Peternakan, UIN Sultan Syarif Kasim Riau dengan nomor register: 001/KEP.FPP/07/2020.

\section{Bahan dan Alat}

Bahan yang digunakan dalam penelitian ini adalah akuades, daun pepaya, Mannitol Salt Agar (MSA), Plate Count Agar (PCA), NaCl, povidone iodine dan sample susu kambing (50 ml/ekor) yang diperoleh dari 16 ekor kambing PE laktasi.

Alat yang digunakan dalam penelitian ini meliputi kertas, alat tulis, lap/tisu, sticky notes, botol plastik, teat dipper, timbangan, nampan, ice box, baskom, pisau, gunting, panci, kompor, saringan, ceret ukur, $\mathrm{pH}$ meter digital, pipet tetes, gelas ukur, tabung kaca, cawan petri, batang pengaduk, inkubator, autoclave dan peralatan laboratorium pendukung lainnya.

\section{Lokasi Penelitian}

Pengaplikasian perlakuan (teat dipping) dan pengambilan sampel susu dalam penelitian dilakukan di peternakan kambing Peranakan Etawa pribadi Bpk. Abdul Rahim, desa Simpang Padang, Kecamatan Bathin Solapan, Kota Duri, Kabupaten Bengkalis. Pengujian jumlah bakteri $S$. aureus dalam penelitian dilakukan di Laboratorium Mikrobiologi, Fakultas Kedokteran, Universitas Riau.

\section{Metode Penelitian}

Penelitian menggunakan metode berupa eksperimen dengan 4 perlakuan dan 4 ulangan. Ulangan penelitian berupa 16 ekor kambing PE laktasi yang diambil susunya sebagai sampel. Sedangkan untuk perlakuan berupa persentase dekok daun pepaya sebagai berikut:

P0: Povidone Iodine 10\%

P1: 300 g daun pepaya $+1.000 \mathrm{ml}$ air $(30 \%)$ 
Penggunaan Dekok Daun Pepaya (Carica papaya L.) pada Perlakuan Teat Dipping terhadap Penurunan Jumlah Bakteri Staphylococcus aureus dalam Susu Kambing Peranakan Etawa (Abni, dkk.)

P2: $500 \mathrm{~g}$ daun pepaya $+1.000 \mathrm{ml}$ air $(50 \%)$

P3: $700 \mathrm{~g}$ daun pepaya $+1.000 \mathrm{ml}$ air $(70 \%)$

\section{Prosedur Pemeliharan Ternak Kambing PE}

Sampel 16 ekor kambing PE pada penelitian ini telah mendapatkan sistem pemeliharaan, pakan dan manajemen kandang yang homogen. 16 ekor kambing PE sampel dipelihara dengan sistem pemeliharaan intensif dalam kandang panggung tipe tail to tail. Pakan hijauan untuk 16 ekor kambing PE sampel diberikan 2 kali sehari, dengan jumlah yang sama untuk tiap-tiap kambing yakni $3 \mathrm{~kg}$ pada pagi dan $3 \mathrm{~kg}$ sore hari. Ternak kambing juga diberikan pakan tambahan berupa ampas tahu setiap 2 kali seminggu, diberikan $3 \mathrm{~kg} /$ ekor pada sore hari sebelum pemberian pakan hijauan. Kebersihan kandang untuk 16 ekor kambing PE sampel juga diperlakukan sama, yakni dibersihkan setiap 1 kali sehari dan penyemprotan desinfektan 2 kali seminggu.

\section{Prosedur Pembuatan Dekok Daun Pepaya sebagai Larutan Teat Dipping}

Metode pembuatan dekok daun pepaya sebagai larutan teat dipping diambil dan dimodifikasi dari pembuatan dekok daun kersen oleh Kurniawan dkk. (2013) sebagai berikut:

1. Daun pepaya yang masih hijau dikumpulkan dan dicuci bersih, kemudian ditiriskan hingga bebas air.

2. Setelah kering, daun pepaya dicincang kasar, kemudian direbus dalam air mendidih selama 30 menit dengan persentase 30\%, 50\% dan $70 \%$.

3. Rebusan daun pepaya kemudian disaring untuk memisahkan antara daun dengan air hasil rebusan.

4. Air hasil rebusan kemudian didiamkan hingga suhu $36-37^{\circ} \mathrm{C}$. Air hasil rebusan siap digunakan sebagai larutan teat dipping dalam penelitian.

\section{Prosedur Pengaplikasian Dekok Daun Pepaya sebagai Larutan Teat Dipping}

Pengaplikasian dekok daun pepaya sebagai larutan teat dipping pada kambing PE dilakukan dalam rentang waktu 10 hari. Proses teat dipping dilakukan setelah pemerahan selama hari ke-1 sampai hari ke-10. Sampel susu sebelum perlakuan dikumpulkan pada hari ke-0, sedangkan sampel susu setelah perlakuan dikumpulkan pada hari ke-11.

\section{Pengukuran Nilai pH}

Nilai $\mathrm{pH}$ dari sampel susu diukur menggunakan $\mathrm{pH}$ meter digital. Tujuan dilakukannya pengukuran adalah untuk mengetahui $\mathrm{pH}$ susu sebelum dan sesudah perlakuan.

\section{Penentuan Total Plate Count (TPC) Bakteri}

Sampel susu segar diencerkan menggunakan $\mathrm{NaCl}$ pengenceran $10^{-1}$ sampai dengan pengenceran $10^{-5}$. Pengenceran $10^{-3}, 10^{-4}$ dan $10^{-5}$ masing-masing diambil sebanyak $1 \mathrm{ml}$ lalu dimasukkan ke dalam cawan petri steril. Selanjutnya dituangkan $12-15 \mathrm{ml}$ larutan Plate Count Agar (PCA) hangat $\left(40^{\circ}-50^{\circ} \mathrm{C}\right)$ ke dalam cawan petri yang berisi sampel dan kedua bahan dihomogenkan dengan cara diputar membentuk angka 8. Cawan petri lalu dibalikkan apabila telah mengeras, kemudian diinkubasikan pada suhu $37^{\circ} \mathrm{C}$ selama $24-48$ jam dan dihitung jumlah koloni bakteri yang tumbuh.

\section{Penghitungan Jumlah Koloni Bakteri S. aureus}

Penghitungan jumlah koloni bakteri $S$. aureus menggunakan Mannitol Salt Agar (MSA). MSA yang digunakan terdiri dari $10 \mathrm{~g}$ pepton, $10 \mathrm{~g}$ mannitol, $15 \mathrm{~g}$ agar, $17 \mathrm{~g}$ sodium chloride dan 0,25 g phenol red. Bahan-bahan tersebut dilarutkan dalam $500 \mathrm{ml}$ akuades, kemudian dipanaskan sampai bahan terlarut sempurna. Media disterilisasi menggunakkan autoclave pada tekanan $1 \mathrm{~atm}$ dan suhu $121^{\circ} \mathrm{C}$ selama \pm 15 menit lalu didinginkan suhu $36-37^{\circ} \mathrm{C}$, kemudian media dituangkan ke dalam cawan petri steril dan didiamkan hingga menjadi padat.

Sampel susu yang diuji dituangkan pada media Mannitol Salt Agar (MSA) sebanyak $1 \mathrm{ml}$, lalu didiamkan 2-5 menit agar bakteri merata pada media. Setelah itu, diinkubasi pada suhu $37^{\circ} \mathrm{C}$ selama $24-48$ jam dan dihitung koloni yang berbentuk bulat, licin, berwarna kuning dengan diameter 2-4 $\mathrm{mm}$ dan bersifat mannitol fermenter yang tumbuh pada media.

\section{Persyaratan Mutu Susu Segar}

Adapun syarat mutu susu segar yang dijadikan sebagai salah satu sumber rujukan 
dalam penelian mengacu pada syarat mutu susu segar menurut Standar Nasioanl

Indonesisa (SNI) (2011), dapat dilihat pada tabel berikut ini:

Tabel 1. Persyaratan Mutu Susu Segar

\begin{tabular}{ccc}
\hline No & Jenis Cemaran Mikroba & Batas Maksimum Cemaran Mikroba (BMCM) \\
\hline 1. & Jumlah Total (Total Plate Count) & $1 \times 10^{6}$ \\
2. & Coliform & $2 \times 10^{1}$ \\
3. & Escherichia coli (Patogen) & 0 \\
4. & Enterococci & $1 \times 10^{2}$ \\
5. & Staphylococcus aureus & $1 \times 10^{2}$ \\
6. & Clostridium sp & 0 \\
7. & Salmonella sp & Negatif \\
8. & Camphylobacter sp & 0 \\
9. & Listeria coli & 0 \\
\hline
\end{tabular}

Ket: *dalam satuan MPN/g atau ml

${ }^{* *}$ Dalam satuan kuaitatif (SNI, 2011)

\section{Analisis Data}

Data yang diperoleh dari hasil pengujian dibahas sesuai literatur terkait dan dianalisis secara statistik dengan menggunakan sidik ragam (analysis of variance/ANOVA). Adapun Rancangan yang digunakan adalah Rancangan Acak Lengkap (RAL) sebagai berikut:

$Y i j=\mu i+\tau i+\varepsilon i j ; i=1,2, \ldots, t ; j=1,2, \ldots, r$

Ket:

Yij : Pengamatan pada perlakuan ke-i dan ulangan ke-j

M : Rataan umum

$\mathrm{Ti}$ : Pengaruh perlakuan ke-i

Eij : Komponen galat (Muhammad dkk., 2014).

Jika hasil analisis ragam menunjukkan pengaruh yang atau sangat nyata maka analisa data dilanjutkan dengan menggunakan uji rentang ganda (Duncan Multiple Range Test/ DMRT). Hipotesis statistik yang diterapkan adalah:

1. H0: $\tau 1=\ldots=\tau i=0$ (perlakuan tidak berpengaruh terhadap respons yang diamati)

2. H1: paling sedikit ada satu i dimana $\mathrm{ti} \neq 0$ (ada pengaruh perlakuan terhadap respons yang diamati).

\section{HASIL DAN PEMBAHASAN}

\section{Nilai pH Sampel Susu Kambing PE}

Setelah dilakukan dipping menggunakan dekok daun pepaya selama 10 hari, maka didapatkan nilai rata-rata $\mathrm{pH}$ sampel susu kambing PE sebagai berikut:

Tabel 2. Pengamatan nilai pH sampel susu kambing PE

\begin{tabular}{|c|c|c|c|c|c|}
\hline \multirow{2}{*}{ Perlakuan } & \multicolumn{4}{|c|}{ Ulangan } & \multirow{2}{*}{ Rata-Rata } \\
\hline & I & II & III & IV & \\
\hline P0 & 6,59 & 6,56 & 6,56 & 6,55 & $6,57^{a}$ \\
\hline P1 & 6,47 & 6,49 & 6,49 & 6,54 & $6,50^{\mathrm{b}}$ \\
\hline P2 & 6,48 & 6,46 & 6,50 & 6,50 & $6,49^{b}$ \\
\hline P3 & 6,56 & 6,59 & 6,58 & 6,53 & $6,57^{\mathrm{a}}$ \\
\hline
\end{tabular}

Ket: Superskrip yang berbeda pada kolom yang sama menunjukkan peberbedaan yang sangat nyata $(\mathrm{P}<0,01)$. $\mathrm{P} 0=$ povidone iodine $10 \%, \mathrm{P} 1=$ dekok daun pepaya $30 \%, \mathrm{P} 2=$ dekok daun pepaya $50 \%, \mathrm{P} 3=$ dekok daun pepaya $70 \%$.

Hasil ANOVA menunjukkan perlakuan teat dipping berpengaruh sangat nyata $(\mathrm{P}<0,01)$ terhadap nilai rata-rata $\mathrm{pH}$ dari sampel susu. Diduga adanya pengaruh yang sangat nyata antara perlakuan teat dipping terhadap nilai rata-rata $\mathrm{pH}$ dari sampel susu PE yang diteliti didasari oleh perlakuan teat dipping yang menekan laju bertumbuhan mikroorganisme patogen sehingga $\mathrm{pH}$ susu menjadi stabil (6,3$6,75)$. 
Penggunaan Dekok Daun Pepaya (Carica papaya L.) pada Perlakuan Teat Dipping terhadap Penurunan Jumlah Bakteri Staphylococcus aureus dalam Susu Kambing Peranakan Etawa (Abni, dkk.)

Berdasarkan DMRT, tidak adanya perbedaan yang sangat nyata $(P>0,01)$ antara nilai rata-rata $\mathrm{pH}$ pada perlakuan $\mathrm{P} 0$ dan $\mathrm{P} 3$. Namun kedua perlakuan tersebut (P0 dan P3) memiliki perbedaan yang sangat nyata $(\mathrm{P}<0,01)$ dengan perlakuan P1 dan P2. Hal ini menunjukkan P3 memiliki tingkat efektivitas yang sama terhadap kestabilan nilai $\mathrm{pH}$ sampel dengan P0 yang berbahan dasar povidone iodine $10 \%$. Sedangkan P1 dan P2 belum memiliki efektifitas yang sama dengan $\mathrm{P} 0$.

Nilai rata-rata $\mathrm{pH} \mathrm{P0}$ tidak berbeda sangat nyata dengan nilai rata-rata $\mathrm{pH} \mathrm{P} 3$, yaitu samasama berada pada nilai 6,57. Nilai rata-rata $\mathrm{pH}$ tersebut berada dalam rentang $\mathrm{pH}$ susu segar normal, yakni 6,3-6,75 (Suwito dan Indarjulianto, 2013). Perbedaan yang sangat nyata pada nilai rata-rata $\mathrm{pH} \mathrm{P0}$ dengan nilai rata-rata $\mathrm{pH} \mathrm{P} 1$ dan $\mathrm{P} 2$, yakni secara berturut turut 6,57 (P0); 6,50 (P1); dan 6,49 (P2). Nilai rata-rata $\mathrm{pH} \mathrm{P} 1$ dan $\mathrm{P} 2$ juga masih berada dalam rentang $\mathrm{pH}$ susu segar normal.

Tingkat efektivitas yang sama, tidak berbeda sangat nyata antara P0 dan P3 dalam DMRT, menunjukkan kinerja zat aktif yang ada dalam dekok daun pepaya $70 \%$ memiliki efektivitas yang sama dengan kinerja zat aktif povidone iodine $10 \%$ dalam mengurangi cemaran dan menekan pertumbuhan mikroba patogen yang dapat merusak nilai $\mathrm{pH}$ dari sampel susu. Cemaran mikroorganisme patogen sangat memengaruhi nilai dari $\mathrm{pH}$ susu, dimana semakin tinggi kontaminasi susu terhadap bakteri maka $\mathrm{pH}$ susu akan semakin asam.

Pengasaman susu ini disebabkan tingginya aktifivitas mikroorganisme yang memecah laktosa menjadi asam laktat, sehinga membuat susu berbau dan terasa asam. $\mathrm{pH}$ susu segar di bawah 6,3 menandakan penanganan susu yang tidak higienis, sehingga terjadi peningkatan kontaminasi bakteri pemecah laktosa, antara lain Streptococcus sp. dan Coliform.

Dekok daun pepaya $70 \%$ yang digunakan pada P3 mengandung zat aktif phenol, alkaloid carpaine, flavonoid dan saponin sebagai antiseptik, antiinflamasi, antifungal dan antibakteri, sehingga mampu menekan pertumbuhan mikroorganisme patogen yang membuat $\mathrm{pH}$ susu berada diluar batas normal. Mekanisme kerja zat aktif sebagai antibakteri dengan cara mencemari protoplasma, mengendapkan protein sel bakteri, merusak dan menembus dinding sel bakteri. Rusaknya sistem metabolisme, akan membuat pertumbuhan dan perkembangan bakteri patogen terganggu sehingga bakteri mengalami kerusakan dan kematian. Matinya bakteri patogen akan mengurangi kerusakan pada susu, sehingga susu akan rendah cemaran mikroba dan nilai $\mathrm{pH}$ susu akan tetap terjaga $(6,3-6,75)$.

Selanjutnya, perbedaan yang sangat nyata dalam DMRT antara P0 dengan P1 dan P2 menunjukkan kinerja zat aktif yang ada dalam dekok daun pepaya $30 \%$ dan $50 \%$ belum seefektif kinerja zat aktif povidone iodine $10 \%$. Hal ini diduga, tingkat konsentrasi dekok daun pepaya pada P1 dan P2 (30\% dan 50\%) yang rendah. Sehingga belum mampu bertindak sebagai antibakteri dan mempertahankan nilai pH sampel susu.

\section{Total Plate Count (TPC) Sampel Susu Kambing PE}

Setelah dilakukan dipping menggunakan dekok daun pepaya selama 10 hari, maka didapatkan nilai rata-rata (TPC) sampel sebagai berikut:

Tabel 3. Pengamatan total plate count (TPC) sampel susu kambing PE (CFU/g)

\begin{tabular}{ccccccc}
\hline \multirow{2}{*}{ Perlakuan } & \multicolumn{4}{c}{ Ulangan } & Rata-Rata \\
\cline { 2 - 6 } & I & II & III & IV & $\left.\mathbf{( 1 0}^{6}\right)$ \\
\hline P0 & 0,03 & 0,03 & 0,03 & 0,03 & $0,03^{\mathrm{a}}$ \\
P1 & 1,78 & 1,85 & 1,78 & 1,77 & $1,79^{\mathrm{c}}$ \\
P2 & 1,47 & 1,55 & 1,44 & 1,47 & $1,48^{\mathrm{b}}$ \\
P3 & 0,03 & 0,03 & 0,03 & 0,04 & $0,03^{\mathrm{a}}$ \\
\hline
\end{tabular}

Ket: Superskrip yang berbeda pada kolom yang sama menunjukkan perbedaan yang sangat nyata $(\mathrm{P}<0,01)$. $\mathrm{P} 0=$ povidone iodine $10 \%, \mathrm{P} 1=$ dekok daun pepaya $30 \%, \mathrm{P} 2=$ dekok daun pepaya $50 \%, \mathrm{P} 3=$ dekok daun pepaya $70 \%$. 
Hasil ANOVA menunjukkan perlakuan teat dipping berpengaruh yang sangat nyata $(\mathrm{P}<0,01)$ terhadap penurunan nilai TPC dari sampel susu PE yang diteliti. Diduga dengan diberikan perlakuan teat dipping, membuat tingkat kehigienisan puting lebih tinggi, sehingga susu yang dihasilkan akan lebih sehat, bersih dan rendah cemaran mikroba.

Hal ini sesuai dengan Sasongko dkk. (2012) yang menyatakan dipping menggunakan antiseptik dapat melapisi saluran-saluran susu pada puting agar tidak terkontaminasi bakteri dari lingkungan sekitar yang dapat menyebabkan turunnya kualitas susu. Larutan dipping bekerja dengan cara melapisi dinding jaringan ambing dengan zat aktif dalam antiseptik sehinga mencegah mikroorganisme masuk dan berkembang (Priono dkk., 2016).

Berdasarkan DMRT, didapatkan tidak adanya perbedaan yang sangat nyata $(P>0,01)$ antara nilai rata-rata TPC pada perlakuan P0 dan P3. Namun kedua perlakuan tersebut (P0 dan P3) memiliki perbedaan yang sangat nyata $(\mathrm{P}<0,01)$ dengan perlakuan $\mathrm{P} 1$ dan $\mathrm{P} 2$. Hal ini menunjukkan P3 memiliki tingkat efektivitas yang sama dengan $\mathrm{P0}$ dalam mengurangi nilai TPC sampel. Sedangkan P1 dan P2 belum memiliki efektifitas yang sama dengan $\mathrm{P} 0$.

Nilai rata-rata TPC P0 tidak berbeda sangat nyata dengan nilai rata-rata TPC P3, yaitu $0,03 \times 10^{6}(\mathrm{P} 0)$ dan $0,03 \times 10^{6}(\mathrm{P} 3)$. Nilai rata-rata TPC tersebut tidak melebihi nilai TPC dari Batas Maksimum Cemaran Mikroba (BMCM) susu segar menurut SNI (2011), yaitu 1 $x 10^{6} \mathrm{CFU} / \mathrm{ml}$. Perbedaan yang sangat nyata pada nilai rata-rata TPC P0 dengan nilai ratarata TPC $\mathrm{P} 1$ dan $\mathrm{P} 2$, yakni secara berturut turut $0,03 \times 10^{6}(\mathrm{P} 0) ; 1,79 \times 10^{6}(\mathrm{P} 1)$; dan $1,48 \times 10^{6}(\mathrm{P} 2)$. Nilai rata-rata TPC P1 dan P2 melebihi nilai TPC dari Batas Maksimum Cemaran Mikroba (BMCM) susu segar menurut SNI (2011).

Tingkat efektivitas yang sama, tidak berbeda sangat nyata antara P0 dan P3 dalam DMRT, menunjukkan kinerja zat aktif dekok daun pepaya $70 \%$ memiliki efektifitas yang sama dengan kinerja zat aktif povidone iodine $10 \%$. Dekok daun pepaya $70 \%$ dalam P3 mengandung zat aktif alkaloid carpaine, flavonoid, saponin, tannin dan poliphenol. Zat-zat aktif tersebut bersifat sebagai antiseptik, antiinflamasi, antifungal dan antibakteri. Selain zat aktif phenol dan alkaloid, daun pepaya juga mengandung zat aktif flavonoid dan saponin yang berperan sebagai antimikroba dan antivirus (Kurniawan dkk., 2013).

Mekanisme kerja zat aktif sebagai antibakteri dengan cara mencemari protoplasma, mengendapkan protein sel bakteri, merusak dan menembus dinding sel bakteri. Senyawa phenol mampu menginaktifkan enzim esensial di dalam sel bakteri, walaupun dengan konsentrasi rendah. Senyawa phenol mampu memutuskan ikatan peptidoglikan pada dinding sel, yaitu dengan cara merusak ikatan hidrofobik komponen membran sel (seperti protein dan fosfolipida) (Tuntun, 2016). Larutnya komponen-komponen yang berikatan secara hidrofobik akan berakibat meningkatnya permeabilitas membran. Hal ini menyebabkan kebocoran sehingga keluarnya isi sel. Terjadinya kerusakan pada membran sel mengakibatkan terhambatnya aktivitas dan biosintesis enzim-enzim spesifik yang diperlukan dalam reaksi metabolisme (Tuntun, 2016).

Alkaloid carpaine memiliki gugus basa yang dapat bereaksi dengan DNA bakteri. Reaksi ini akan merusak DNA bakteri sehingga menyebabkan rusaknya inti sel bakteri. Kerusakan sel membuat bakteri tidak mampu melakukan metabolisme sehingga mengalami lisis, dengan demikian bakteri menjadi inaktif dan hancur (Tuntun, 2016).

Flavonoid merupakan senyawa yang bersifat desinfektan yang bekerja dengan cara mendenaturasi protein yang mengkatalisasi semua aktifitas metabolisme sel bakteri. Berhentinya aktifitas metabolisme ini akan mengakibatkan kematian sel bakteri. Flavonoid memiliki tiga mekanisme yang memberikan efek antibakteri, antara lain dengan menghambat sintesis asam nukleat, menghambat fungsi sitoplasma dan menghambat metabolisme energi.

Saponin berasa pahit, berbusa dalam air dan bersifat antimikroba. Saponin akan bekerja sebagai antibakteri dengan cara mengganggu tegangan permukaan dinding sel, maka saat tegangan permukaan terganggu zat antibakteri akan masuk dengan mudah kedalam sel dan 
Penggunaan Dekok Daun Pepaya (Carica papaya L.) pada Perlakuan Teat Dipping terhadap Penurunan Jumlah Bakteri Staphylococcus aureus dalam Susu Kambing Peranakan Etawa (Abni, dkk.)

akan mengganggu metabolisme hingga akhirnya terjadilah kematian bakteri (Karlina, dkk., 2013).

Selanjutnya, perbedaan yang sangat nyata dalam DMRT antara P0 dengan P1 dan P2 menunjukkan kinerja zat aktif yang ada dalam dekok daun pepaya $30 \%$ dan $50 \%$ belum seefektif kinerja zat aktif povidone iodine 10\%. Hal ini diduga, tingkat konsentrasi dekok daun pepaya pada P1 dan P3 (30\% dan 50\%) yang rendah. Sehingga belum mampu bertindak sebagai antibakteri dengan cara mencemari protoplasma, mengendapkan protein sel bakteri, merusak dan menembus dinding sel bakteri. Hal ini sejalan dengan penelitian Karlina dkk. (2012) mengenai antibakteri ekstrak krokot terhadap pertumbuhan bakteri S. aureus secara in Vitro yang menunjukkan semakin tinggi konsentrasi antibakteri maka semakin luas zona hambat bakteri.

\section{Jumlah Koloni Bakteri S. aureus (Uji Mannitol} Salt Agar/ MSA) Sampel Susu Kambing PE

Setelah dilakukan dipping menggunakan dekok daun pepaya selama 10 hari, maka didapatkan nilai dari rata-rata jumlah koloni bakteri $S$. aureus sebagai berikut:

Tabel 4. Pengamatan jumlah bakteri S. aureus (uji mannitol salt agar/ MSA) sampel susu kambing PE $(\mathrm{CFU} / \mathrm{g})$

\begin{tabular}{ccccccc}
\hline \multirow{2}{*}{ Perlakuan } & \multicolumn{9}{c}{ Ulangan $\left(10^{2}\right)$} & Rata-Rata \\
\cline { 2 - 5 } & I & II & III & IV & $\left(10^{2}\right)$ \\
\hline P0 & 0,68 & 0,59 & 0,68 & 0,72 & $0,67 \mathrm{a}$ \\
P1 & 2,72 & 2,68 & 2,70 & 2,70 & $2,70 \mathrm{c}$ \\
P2 & 0,97 & 1,01 & 1,04 & 0,95 & $0,99 \mathrm{~b}$ \\
P3 & 0,69 & 0,65 & 0,69 & 0,63 & $0,67 \mathrm{a}$ \\
\hline
\end{tabular}

Ket: Superskrip yang berbeda pada kolom yang sama menunjukkan peberbedaan yang nyata $(\mathrm{P}<0,01)$. $\mathrm{P} 0=$ povidone iodine $10 \%, \mathrm{P} 1=$ dekok daun pepaya $30 \%, \mathrm{P} 2=$ dekok daun pepaya $50 \%$, P3= dekok daun pepaya $70 \%$.

Hasil ANOVA menunjukkan perlakuan teat dipping berpengaruh sangat nyata $(\mathrm{P}<0,01)$ terhadap nilai rata-rata jumlah koloni $S$. aureus dari sampel susu PE yang diteliti. Pengaruh yang sangat nyata antara perlakuan teat dipping terhadap nilai rata-rata jumlah koloni $S$. aureus dikarenakan kemampuan teat dipping menekan pertubuhan S. aureus tersebut.

Hal ini sejalan dengan pendapat Kurniawan dkk. (2013) fungsi dari pencelupan puting adalah dapat menurunkan dan menekan jumlah sel somatik, sehingga kejadian mastitis dapat ditekan. Nickerson (2013) juga menyatakan mencelupkan puting di akhir pemerahan sangat efektif untuk mencegah infeksi baru yang disebabkan oleh mikroorganisme penyebab mastitis yang menular seperti S. aureus dan S. agalactiae.

Berdasarkan DMRT, tidak adanya perbedaan yang sangat nyata $(P>0,01)$ antara nilai rata-rata jumlah koloni $S$. aureus pada perlakuan P0 dan P3. Namun kedua perlakuan tersebut (P0 dan P3) memiliki perbedaan yang sangat nyata $(\mathrm{P}<0,01)$ dengan perlakuan $\mathrm{P} 1$ dan P2. Hal ini menunjukkan P3 memiliki tingkat efektivitas yang sama dengan P0 dalam mengurangi nilai rata-rata jumlah koloni bakteri S. aureus sampel. Sedangkan P1 dan P2 belum memiliki efektifitas yang sama dengan P0.

Nilai rata-rata jumlah koloni $S$. aureus P0 tidak berbeda sangat nyata dengan nilai ratarata jumlah koloni $S$. aureus P3, yaitu $0,67 \times 10^{2}$ (P0) dan $0,67 \times 10^{2}$ (P3). Nilai rata-rata jumlah koloni $S$. aureus tersebut tidak melebihi Batas Maksimum Cemaran Mikroba (BMCM) S. aureus pada susu segar menurut SNI (2011), yaitu $1 \times 10^{2} \mathrm{CFU} / \mathrm{ml}$. Perbedaan yang sangat nyata pada nilai rata-rata jumlah koloni $S$. aureus $\mathrm{P} 0$ dengan nilai rata-rata jumlah koloni $S$. aureus $\mathrm{P} 1$ dan $\mathrm{P} 2$, yakni secara berturut turut $0,67 \times 10^{2}$ (P0); 2,7 x 102 (P1); dan 0,99 × $10^{2}$ (P2). Nilai rata-rata jumlah koloni $S$. aureus pada perlakuan P1 melebihi Batas Maksimum Cemaran Mikroba (BMCM) S. aureus pada susu segar menurut SNI (2011). Sedangkan nilai ratarata jumlah koloni $S$. aureus P2 sangat 
mendekati Batas Maksimum Cemaran Mikroba (BMCM) S. aureus pada susu segar menurut SNI (2011).

Tidak adanya berbeda yang sangat nyata antara P0 dan P3 dalam DMRT menunjukkan zat aktif phenol, alkaloid, flavonoid dan saponin dekok daun pepaya $70 \%$ memiliki efektivitas yang sama dengan povidone iodine 10\% dalam menekan dan menghambat pertumbuan bakteri S. aureus pada sampel susu. Zat-zat aktif tersebut bekerja dengan cara mencemari protoplasma, mengendapkan protein sel bakteri, merusak dan menembus dinding sel bakteri.

Bakteri S. aureus merupakan bakteri Gram positif yang memiliki dinding sel lebih dengan kandungan lipid yang tipis (1-4\%), sehingga senyawa phenol yang bersifat sebagai antibakteri akan lebih mudah masuk dan merusak dinding sel S. aureus. Rusaknya dinding sel akan membentuk zona hambat dan mengganggu sistem metabolisme $S$. aureus tersebut. Larutnya komponen-komponen yang berikatan secara hidrofobik akan berakibat meningkatnya permeabilitas membran. Hal ini menyebabkan kebocoran sehingga keluarnya isi sel. Terjadinya kerusakan pada membran sel mengakibatkan terhambatnya aktivitas dan biosintesis enzim-enzim spesifik yang diperlukan dalam reaksi metabolisme (Tuntun, 2016).

Alkaloid carpaine bekerja dengan cara mengganggu metabolisme nukleoid S. aureus, sehingga DNA $S$. aureus akan mengalami gangguan dan mati. Sebagaimana yang dijelaskan oleh Tuntun (2016) Alkaloid carpaine memiliki gugus basa yang dapat bereaksi dengan DNA bakteri. Reaksi ini akan merusak DNA bakteri sehingga menyebabkan rusaknya inti sel bakteri. Kerusakan sel membuat bakteri tidak mampu melakukan metabolisme sehingga mengalami lisis, dengan demikian bakteri menjadi inaktif dan hancur (Tuntun, 2016).

Flavonoid merupakan senyawa yang bersifat desinfektan yang bekerja dengan cara mendenaturasi protein yang mengkatalisasi semua aktifitas metabolisme sel bakteri. $S$. aureus merupakan bakteri yang aktifitas selnya juga dikatalisis oleh protein, sehingga penggunaan dekok daun pepaya sebagai larutan teat dipping yang mengandung zat aktif flavonoid akan ikut mendenaturasi protein dan membunuh S. aureus.

Sistem kerja saponin sebagai antibakteri adalah dengan masuk melalui dinding sel dan mengganggu sistem metabolisme bakteri dari dalam. Saponin dalam dekok daun pepaya $70 \%$ akan merusak dinding sel dan mengganggu metabolisme $S$. aureus hingga menyebabkan kematian pada S. aureus tersebut.

Saponin akan lebih mudah merusak dinding sel $S$. aureus dikarenakan $S$. aureus merupakan bakteri Gram positif yang memiliki dinding sel yang lebih tipis dibandingkan dengan dinding sel dari bakteri Gram negatif. Tuntun (2016) menyebutkan dinding sel bakteri Gram negatif mengandung lipid lebih banyak $(11-22 \%)$ daripada bakteri Gram positif (1-4\%). Hal ini sejalan dengan pendapat Karlina dkk. (2013) saponin akan bekerja sebagai antibakteri dengan cara mengganggu tegangan permukaan dinding sel, maka saat tegangan permukaan terganggu zat antibakteri akan masuk dengan mudah ke dalam sel dan akan mengganggu metabolisme hingga akhirnya terjadilah kematian bakteri (Karlina, dkk., 2013).

Selanjutnya, adanya perbedaan yang sangat nyata dalam DMRT antara P0 dengan P1 dan P2 menunjukkan kinerja zat aktif yang ada dalam dekok daun pepaya $30 \%$ dan $50 \%$ belum seefektif kinerja zat aktif povidone iodine $10 \%$. Hal ini diduga, tingkat konsentrasi dekok daun pepaya pada P1 dan P3 (30\% dan 50\%) yang rendah. Sehingga belum mampu bertindak sebagai antibakteri dengan cara mencemari protoplasma, mengendapkan protein sel bakteri, merusak dan menembus dinding sel bakteri.

\section{KESIMPULAN}

Berdasarkan penelitian penggunaan dekok daun pepaya (Carica papaya L.) pada perlakuan teat dipping terhadap penurunan jumlah bakteri Staphylococcus aureus dalam susu kambing Peranakan Etawa disimpulkan penggunaan dekok daun pepaya sebagai larutan teat dipping mampu mempertahankan nilai $\mathrm{pH}$, menurunkan nilai Total Plate Count (TPC) dan nilai jumlah koloni bakteri S. aureus pada sampel susu kambing PE. Dekok daun 
Penggunaan Dekok Daun Pepaya (Carica papaya L.) pada Perlakuan Teat Dipping terhadap Penurunan Jumlah Bakteri Staphylococcus aureus dalam Susu Kambing Peranakan Etawa (Abni, dkk.)

pepaya $70 \%$ merupakan dekok daun pepaya dengan konsentrasi terbaik yang memiliki tingkat efektivitas yang sama dengan penggunaan povidone iodine $10 \%$ sebagai larutan teat dipping.

\section{KONFLIK KEPENTINGAN}

Berdasarkan pernyataan ini penulis dan seluruh tim peneliti menyatakan tidak sedang memiliki konflik kepentingan yang berhubungan dengan keuangan, pribadi atau lainnya dengan orang atau organisasi lain yang terkait dengan materi yang dibahas dalam naskah.

\section{UCAPAN TERIMA KASIH}

Terima kasih kepada Bapak Abdul Rahim, selaku pemilik peternakan kambing etawa, desa Simpang Padang, Kecamatan Bathin Solapan, Kota Duri, Kabupaten Bengkalis yang sudah berkenan membantu dan mengizinkan penulis dan tim untuk melakukan penelitian di peternakannya.

\section{DAFTAR PUSTAKA}

A'yun, Q. \& A.N. Laily. 2015. Analisisi Fitokimia Daun Pepaya (Carica papaya L.) di Balai Penelitian Tanaman Aneka Kacang dan Umbi, Kendalpayak, Malang. Seminar Nasional Konservasi dan Pemanfaatan Sumber Daya Alam 2015, SP003 - 020.

Albenzio, M. \& A. Santilo. 2011. Biochemical Characteristic of Ewe and Goat Milk: Effect on the Quality of Dairy Products. Small Ruminant Research, 101: 33-40.

Karlina, C.Y., M. Ibrahim \& G. Trimulyono. 2013. Aktivitas Antibakteri Ekstrak Herba Krokot (Portulaca oleracea L.) terhadap Staphylococcus aureus dan Escherichia coli. E Journal UNESA Lentera-Bio, 2(1): 87-93.

Kurniawan, I., P. Sarwiyono \& Surjowardojo. 2013. Pengaruh Teat Dipping Menggunakan Dekok Daun Kersen (Muntingia calibura L.) terhadap Tingkat Kejadian Mastitis. Jurnal Ilmu-ilmu Peternakan, 23: 27-31.

Muhammad, I., A. Rusgiyono \& M.A. Mukid. 2014. Penilaian Cara Mengajar Menggunakan
Rancangan Acak Lengkap. Jurnal Gaussian, 3(2): 183-192.

Nickerson, S. 2013. Choosing the best teat dip for mastitis control and milk quality. Hill Farm Reseacrh Station. Thesis. Louisiana State Univesity Agricultural Center. Homer, Loisiana.

Priono, A., E. Kusumanti \& D.W. Harjanti. 2016. Jumlah Bakteri Staphylococcus aureus dan Skor California Mastitis Test (CMT) pada Susu Kambing Peranakan Etawa Akibat Dipping Ekstrak Daun Babadotan (Ageratum conyzoides L.). Jurnal Ilmu-Ilmu Peternakan, 26 (1): 52-57

Sasongko, D.A., T.H. Suprayogi \& S.M. Sayuthi. 2012. Pengaruh Berbagai Konsentrasi Larutan Kaporit $(\mathrm{CaHOCl})$ untuk Dipping Puting Susu Kambing Perah terhadap Total Bakteri dan $\mathrm{Ph}$ Susu. Journal of Animal Agriculture, 1(2): 93-99.

Siregar, A.Z. 2010. Pengaruh Teat Dipping Sari Buah Mengkudu (Morinda citrifolia L.) terhadap Kasus Mastitis Subklinis pada Sapi Perah Berdasarkan Pemeriksaan Total Plate Count. http://www.fkh. unair.ac.id/artikel1 /2010/ ARTIKEL\%20ILMIAH \% 20A.pdf. Diakses: Maret 2020.

Standar Nasional Indonesia 3141.1:2011. Batas Maksimum Cemaran Mikroba dan Batas Maksimum Residu dalam Bahan Makanan Asal Hewan. Badan Standarisasi Nasional.

Suwito, W., A.E.T.H. Wahyuni., W.S. Nugroho \& B. Sumiarto. 2013. Isolasi dan Identifikasi Bakteri Mastitis pada Kambing Peranakan Ettawah. Jurnal Sain Veteriner, 1(31): 49-54.

Suwito, W. \& S. Indarjulianto. 2013. Staphylococcus aureus Penyebab Mastitis pada Kambing Peranakan Etawah: Epidemiologi, Sifat Klinis, Patogenesis, Diagnosis dan Pengendalian. WARTAZOA, 23(1).

Tuntun, M. 2016. Uji Efektivitas Ekstrak Daun Pepaya (Carica papaya L.) terhadap Pertumbuhan Bakteri Escherichia coli dan Staphylococcus aureus. Jurnal Kesehatan, 8(3): 497-502. 